\title{
AN IMPROVED MINERAL NUTRIENT SOLUTION FOR THE IN VITRO PROPAGATION OF PINGUICULA SPECIES
}

LAURENT LeGENDRE • University Claude B ernard Lyon 1 • U M R 5557 • 43 B d du 11 Novembre 1918 -69622 V illeurbanne Cedex • France • laurent.legendre@ univ-st-etienne.fr

Keywords: in vitro cultivation, Pinguicula, tissue culture.

\section{Introduction}

Propagating plants in vitro (tissue culture) is widely used to rapidly generate large quantities of disease-free plants. It is applied to hundreds of carnivorous plant species including the genus Pinguicula whose species are very sensitive to pathogenic microorganisms and, in some cases, may develop poorly under current cultivation practices (L egendre \& K ibellis 2005).

A dams et al. (1979) and Gonçalves et al. (2008) have respectively reported the successful micropropagation of P. moranensis and P. Iusitanica on a diluted version of the mineral nutrient solution originally published by Linsmaier \& Skoog (1965). This was based on the nutrient composition described by M urashige \& Skoog (1962) with modifications of the vitamin content. Nevertheless, most $P$ inguicula species cannot be grown on this nutrient solution because they will develop leaf tip burns (P. moctezumae), reduce in size after each transplanting (P. filifolia), quickly form dormant hibernaculae (all temperate European species), or simply do not grow at all (P. ramosa, P. parvifolia).

This article aims to share some pieces of personal experience and the composition of an improved mineral nutrient solution that alleviates the above-described symptoms and which can be used to successfully propagate most Pinguicula species.

\section{$M$ aterials and $M$ ethods}

Plant material

All species used in this study were obtained from a horticultural company ( $N$ ature et Paysages, France) except $P$. vulgaris, $P$. gigantea, and $P$. macroceras seeds which had been collected from the Champagne state of France, Ayautla, M exico, and Douglas Park, California, USA, respectively. P. sp. "huahuapan" had affinity with P. rectifolia and P. sp. "la vuelta", P. sp. "santa maria yukuhiti" had affinity with P. moranensis. The hybrid P. moctezumae $\times$ P. gigantea was prepared by the author.

\section{Explant sterilisation}

Seeds of all species were surface-sterilized before being introduced to tissue culture vessels. For this, they were soaked for 6 min (with regular vigorous shaking) in a 4\% calcium hypochlorite solution supplemented with $0.1 \%$ Tween- 20 (this solution was filtered immediately before use to discard the detergent-induced bleach precipitates) followed by 3 rinses of $10 \mathrm{~min}$ each in sterile distilled water. D ead seeds and plant debris floated in the surface foam while live seeds sank to the bottom of the tubes. This allowed their easy separation either by specifically sucking away the live seeds with 
a sterile glass Pasteur pipette or by pouring away the sterilizing and rinsing solutions containing the non-seed material.

\section{Growing conditions}

Plants were grown in $5 \mathrm{~cm}$ diameter glass vessels (3-6 plants per pot) in a grow th chamber maintained at constant temperature $\left(23^{\circ} \mathrm{C}\right)$ with an air conditioning unit. They were lit with fluorescent tubes (alternating industrial white and warm, reddish, light tubes, each $10 \mathrm{~cm}$ apart) placed $40 \mathrm{~cm}$ above the plants. Lights were on $16 \mathrm{~h}$ per day.

Liquid media were sterilised by autoclaving at $121^{\circ} \mathrm{C}$ for $20 \mathrm{~min}$. Plant transfers were made in sterile air in laminar flow hoods.

Plants ( $0.5 \mathrm{~cm}$ diameter) were subcultured 3 times on M ix A (see below) before being transferred to $\mathrm{M}$ ix $\mathrm{A}$ or $\mathrm{M}$ ix B for the comparative study. Their diameter was then measured 8 weeks later.

\section{Mineral nutrient solutions}

Distilled water was used to prepare all stock and final solutions.

$\mathrm{M}$ ix A: M acronutrients 10X stock (stored at 4으 for up to 3 months): $\mathrm{NH}_{4} \mathrm{NO}_{3}(16.5 \mathrm{~g} / \mathrm{l}), \mathrm{K} \mathrm{NO}_{3}$ (19.0 g/l), $\mathrm{CaCl}_{2}(3.322 \mathrm{~g} / \mathrm{l}), \mathrm{M} \mathrm{gSO}_{4}(1.807 \mathrm{~g} / \mathrm{l}), \mathrm{KH}_{2} \mathrm{PO}_{4}(1.70 \mathrm{~g} / \mathrm{l})(\mathrm{M}$ urashige $\&$ Skoog 1962).

$\mathrm{M}$ icronutrients $1000 \mathrm{X}$ stock (stored at $-20^{\circ} \mathrm{C}$ for several years): $\mathrm{KI}(0.83 \mathrm{~g} / \mathrm{l}), \mathrm{H}_{3} \mathrm{BO}_{3}(6.2 \mathrm{~g} / \mathrm{l})$, $\mathrm{MnSO}_{4} \cdot \mathrm{H}_{2} \mathrm{O}(16.9 \mathrm{~g} / \mathrm{l}), \mathrm{ZnSO}_{4} \cdot 7 \mathrm{H}_{2} \mathrm{O}(8.6 \mathrm{~g} / \mathrm{l}), \mathrm{CuSO}_{4} .5 \mathrm{H}_{2} \mathrm{O}(0.025 \mathrm{~g} / \mathrm{l}), \mathrm{CoCl}_{2} \cdot 6 \mathrm{H}_{2} \mathrm{O}(0.025 \mathrm{~g} / \mathrm{l})$, $\mathrm{Na}_{2} \mathrm{M} \mathrm{OO}_{4}, 2 \mathrm{H}_{2} \mathrm{O}(0.25 \mathrm{~g} / \mathrm{l})$. This later substance was dissolved separately in $100 \mathrm{ml}$ water before being added to the final micronutrient mix (M urashige \& Skoog 1962).

Fe-EDTA 200X stock (stored at ${ }^{\circ} \stackrel{ }{ } \mathrm{C}$ away from light for up to 3 months): $\mathrm{Na}_{2}$ EDTA ( $7.45 \mathrm{~g} / \mathrm{l}$ dissolved in $900 \mathrm{ml}$ of nearly boiling water), $\mathrm{FeSO}_{4} \cdot 7 \mathrm{H}_{2} \mathrm{O}(1.86 \mathrm{~g} / \mathrm{l}$ added with small increments to boiling hot EDTA). The volume was subsequently adjusted to 1 liter with water. A couple of drops of concentrated $\mathrm{HCl}$ were added if iron salts did not dissolve. Crystals formed in the refrigerator during storage but could be re-dissolved by a quick boil in a microwave oven (D alton et al. 1983).

$V$ itamins $1000 \mathrm{X}$ stock (stored at $-20^{\circ} \mathrm{C}$ for several years): myo-inositol $(100 \mathrm{~g} / \mathrm{l})$, Thiamine. $\mathrm{HCl}$ $(0.4 \mathrm{~g} / \mathrm{l})$, glycine $(2 \mathrm{~g} / \mathrm{l})$ (Linsmaier \& Skoog 1965).

Final mix: $25 \mathrm{ml} / /$ 10X macronutrient stock, $1 \mathrm{ml} / \mathrm{l}$ 1000X micronutrient stock, $3.78 \mathrm{ml} / \mathrm{l} 200 \mathrm{X}$ iron-EDTA stock, $1 \mathrm{ml} / \mathrm{l}$ 1000X vitamin stock, $20 \mathrm{~g} / \mathrm{l}$ sucrose (food grade), pH 5.9 (adjusted with $1 \mathrm{~N} \mathrm{KOH}$ ), $5 \mathrm{~g} / \mathrm{A}$ gargel (Sigma A -3301). This specific grade of A gar gave the best results.

$\mathrm{M}$ ix B : M acronutrients $10 \mathrm{X}$ stock (stored at 4으 for up to 3 months): $\mathrm{NH}_{4} \mathrm{NO}_{3}(4.125 \mathrm{~g} / \mathrm{l}), \mathrm{K} \mathrm{NO}_{3}$ (19.0 g/l), $\mathrm{CaCl}_{2}(3.322 \mathrm{~g} / \mathrm{l}), \mathrm{M} \mathrm{gSO}_{4}(1.807 \mathrm{~g} / \mathrm{l}), \mathrm{KH}_{2} \mathrm{PO}_{4}(1.70 \mathrm{~g} / \mathrm{l})$.

$\mathrm{M}$ icronutrients, Fe-EDTA, and V itamins stocks were the same as in $\mathrm{M}$ ix $\mathrm{A}$.

Final mix: $50 \mathrm{ml} / \mathrm{l}$ 10X macronutrient stock, $1 \mathrm{ml} / \mathrm{l}$ 1000X micronutrient stock, $3.78 \mathrm{ml} / \mathrm{l} 200 \mathrm{X}$ iron-EDTA stock, $1 \mathrm{ml} / \mathrm{l}$ 1000X vitamin stock, $20 \mathrm{~g} / \mathrm{l}$ sucrose (food grade), pH 5.9 (adjusted with $1 \mathrm{~N} \mathrm{KOH}$ ), $5 \mathrm{~g} / \mathrm{l}$ A gargel (Sigma A-3301).

\section{Results and Discussion}

In a first series of experiments, the growth of P. moranensis and P. agnata were compared when grown on serial dilutions of Linsmaier \& Skoog's (1965) nutrient solution (undiluted and 2-, 4-, 
8-, and 16-fold dilutions). The fastest growth was obtained with 4- to 8-fold diluted nutrient solutions in agreement with the formulation used by A dams et al. (1979) and Gonçalves et al. (2008). A comparison of the growth of the same two species on 4-fold diluted nutrient solutions, the $\mathrm{pH}$ of which were either adjusted with $\mathrm{NaOH}$ or with $\mathrm{KOH}$, reveal ed that sodium ions $\left(\mathrm{Na}^{+}\right)$were toxic to these species and the use of $\mathrm{KOH}$ yielded faster growth (data not shown). Similarly, the use of the iron-EDTA formulation developed by Dalton et al. (1983) was found to significantly improve the performance of these two species (prevents iron, and other metal ions, from precipitating during autoclaving). Because repeated transplanting led to regularly more stunted specimens, the nutrient solution was modified to dilute the macronutrients 4 times while maintaining a constant concentration of the other nutrients (micronutrients, iron-EDTA, and vitamins). Several studies have indeed demonstrated that micronutrients can be growth-limiting if their concentrations are half of optimum values that are, more or less, common to most land plants (J ones 1997). A Il of these basic adjustments of composition of the nutrient solution have led to the design of M ix A of the present study.

Nevertheless, other species (most noticeably P. filifolia, for example) did not grow optimally on $\mathrm{M}$ ix $\mathrm{A}$ and displayed reduced growth after each subculture. For this reason, a new formulation (called M ix B) was designed and assayed in a comparative study after an initial round of propagation on M ix A. M ix B differed from M ix A by having half the ammonium nitrate and twice the other macronutrients ( $1 / 8$ the ammonium nitrate and half of the other macronutrients than in $M$ urashige \& Skoog, 1962). As shown in Table 1, M ix B allowed most of the tested Pinguicula species to develop to larger sizes. Species, like P. filifolia and all European temperate species, responded very positively to the change in nutrient solution, while others (from M exico) were unaffected. Typically, those species that exhibited size reduction during subculturing on M ix A were the ones that fared better on M ix B. A II of the species listed in Table 1 were subsequently subcultured 12 times on $\mathrm{M}$ ix $B$ with no significant reduction in grow th rate or size.

\begin{tabular}{|c|c|c|}
\hline \multirow[t]{2}{*}{ Species name } & \multicolumn{2}{|c|}{ Final plant diameter $(\mathrm{cm} \text {; mean } \pm \mathrm{SD})^{*}$} \\
\hline & Mix A & Mix B \\
\hline P. filifolia \# & $4.0 \pm 1.0$ & $8.0 \pm 1.0$ \\
\hline P. grandiflora \# & $1.5 \pm 0.6$ & $3.7 \pm 0.6$ \\
\hline P. longifolia subsp longifolia \# & $2.3 \pm 0.6$ & $4.7 \pm 0.6$ \\
\hline P. moctezumae \# & $3.0 \pm 0.9$ & $5.5 \pm 0.6$ \\
\hline P. vulgaris ${ }^{\#}$ & $1.2 \pm 0.6$ & $3.0 \pm 0.1$ \\
\hline P. macroceras \# & $1.7 \pm 0.5$ & $2.7 \pm 0.6$ \\
\hline P. sp. "huahuapan" ns & $4.0 \pm 1.0$ & $4.3 \pm 0.6$ \\
\hline P. sp. "la vuelta" \# & $2.7 \pm 0.6$ & $3.7 \pm 1.5$ \\
\hline P. sp. "santa maria yukuhiti" \# & $1.5 \pm 0.6$ & $2.5 \pm 0.6$ \\
\hline P. moctezumae $\times$ P. gigantea ${ }^{\text {ns }}$ & $2.7 \pm 0.9$ & $3.0 \pm 0.8$ \\
\hline
\end{tabular}

* 8-week old plants - starting plant diameter: $0.5 \mathrm{~cm}$; \# Significant difference in grow th between the two lots of plants (Student t-test, $p<0.05)$. ns: non-significant $(p>0.05)$. $n=3-6$. 
A set of species that did not develop (or grew very slowly) on M ix A (P. parvifolia, P. heterophylla, P. oblongiloba, and P. ramosa) was directly cultured on M ix B. All species developed surprisingly well on Mix B.

Two interesting observations were made during the comparative study of the nutrient solutions, $M$ ix $A$ and $B$. First of all, long-leaf species such as P. moctezumae and its hybrids developed dead leaf tips on $\mathrm{M}$ ix $\mathrm{A}$, a phenomenon that also occurs occasionally when plants are grown ex vitro (on soil). This disorder was absent from plants grown on M ix B. A dditionally, temperate European species did not form winter buds (and entered dormancy) as quickly on M ix B as on M ix A. So, not only did they develop faster on $\mathrm{M}$ ix $B$, but they remained longer in active growth on this mix, growing larger plants in a shorter time. This suggests that both phenomena may be caused by a deficiency of some minerals.

Unlike in A dams et al. (1979), the exogenous addition of hormones to the tissue culture medium was not an absolute requirement to induce the multiplication of Pinguicula species in vitro (also observed by Gonçalves et al., 2008). All species multiplied spontaneously when left long enough on their growth media.

One drawback of in vitro technology is that it leads to an inevitable drift in the plants genetic make-up. Though tissue cultured plants are multiplied vegetatively, and are therefore, supposed to be genetically equal, somaclonal variants spontaneously arise (even when no hormones are added exogenously). These variants can be unintentionally selected because of the massive number of plants that are generated in comparison to the small number of specimens that are selected when subculturing fresh media for the next round of propagation, especially in the case of species that grow slowly. I have indeed noticed that I was systematically transferring the best-looking (bestgrowing) specimens. This led, for example, to the selection, after two years of micropropagation, of a clone of P. ramosa that was growing much faster and was making plants twice as large as the mother plant from which it originated.

A cknowledgement: The author wishes to thank L ubomir A damec for his careful review and suggestions about this manuscript.

\section{References}

A dams, R.M ., Koenigsberg, S.S., and Langhans, R.W. 1979. In vitro propagation of the butterwort Pinguicula moranensis H.B.K. HortSci. 14: 701-702.

Dalton, C.C., Iqbal, K., and Turner, D.A. 1983. I ron precipitation in M urashige and Skoog media. Physiol. Plant. 57: 472-476.

Gonçalves, S., Escapa, A.L., Grevenstuk, T., and Romano, A . 2008. A n efficient in vitro propagation for Pinguicula Iusitanica, a rare insectivorous plant. Plant Cell Tiss. O rgan Cult. 95: 239-243.

Jones, J.B., J r. 1997. Hydroponics: A practical guide for the soilless grower. St. Lucie Press. B oca Raton, Florida, USA.

Legendre, L., and Kibellis, H. 2005. Disease symptoms in Pinguicula: Some causes and remedies. Carniv. PI. Newslett. 34: 16-23.

Linsmaier, E.M ., and Skoog, F. 1965. O rganic growth factor requirements of tobacco tissue cultures. Physiol. Plant. 18: 100-127.

M urashige, T., and Skoog, F. 1962. A revised medium for rapid growth and bioassays with tobacco tissue cultures. Physiol. Plant. 15: 473-497. 